\title{
1. China and the Maritime Silk Road: from passive to active participant
}

\author{
John N. Miksic
}

\section{INTRODUCTION}

By the Western Han Dynasty, ports in the Malay Peninsula imported objects from China and India. In the Tang period China began to perceive Southeast Asia as an important region in itself, rather than as an intervening region on the way to India. During the Song Dynasty Chinese became active participants in maritime commercial exchanges with the South Seas. Overseas Chinese enclaves of settlement are first documented during the Yuan period. These communities persisted into the early Ming era, but after the last Ming armada sailed home, contact between overseas Chinese and China was interrupted, and most overseas Chinese assimilated into local societies. The premodern Chinese maritime diaspora constitutes a unique but understudied phenomenon in world history which has much to teach us about the history of globalization.

For most of history, Chinese have preferred life on the northern frontier to southern China. The northern area was cold and threatened by attack, but still it was deemed better than the lands south of the Yangzi, which were characterized by zhang (瘴) (miasma), mental stress caused by strange cultures, plants, animals, heat, and diseases such as malaria and leprosy. Generals preferred execution to leading armies into the south; officials assigned to go there sometimes committed suicide. The association of the south with disease and death continued into the Qing Dynasty (Yang 2010).

This horror of the south was counterbalanced by desire for southern luxuries. Scholars and officials were willing to pay handsomely for foreign items because of their beauty or their medicinal properties. In early history, Chinese trade with the outside world, whether by land or sea, was characterized by high-value, low-bulk items in demand among the nobility or the armed forces (particularly horses), but which had no relevance to the general population. This situation began to change during the Tang Dynasty, when economic, technological, and political variables aligned to produce a tremendous expansion of Asian maritime trade, while the overland trade route nearly dried up.

\section{THE ORIGINS OF THE ASIAN MARITIME SPHERE OF INTERACTION}

For thousands of years, travel was dependent on technology powered by animals and humans. Maritime technology along Asia's southern coast experienced several leaps which made sailing much more efficient and reliable. By 2,000 years ago, when the Han Dynasty established control over China's southern coast and northern Vietnam, Malayo-Polynesian sailors had already colonized Madagascar on the western side of the Indian Ocean, as well as the 
western Pacific Ocean, forming the world's first oceanic network of trade and communication (Çœè̀s 1968).

The Malayo-Polynesians were motivated by two factors: quests for prestige, and the search for necessities. From Taiwan, they obtained ornaments made of stone (Hung et al. 2007). The prestigious items were usually obtained through ceremonial exchanges with specific partners; once these formalities were over, they could barter for mundane items such as pots, cloth, and food (Miksic 1984). This system linked islands with different local products into a resilient network which enabled local specializations to evolve, and short-term fluctuations in availability of food due to floods or pestilences could be ameliorated, establishing a relationship of interdependence over broad expanses of ocean. This system also created a more diverse human gene pool. Culturally, this sphere of interaction disseminated new ideas and practices, fostering technological and intellectual evolution.

\section{IMPORTANCE OF TRADE FOR CHINA}

The Zhou Dynasty established tributary exchange with northern nomads as well as groups south of the Yangzi by the fifth century BCE (Lattimore 1962; Wolters 1967, 1970). These exchanges were portrayed as a tribute from barbarians in recognition of imperial virtue, bolstering the emperor's claim to preserving universal harmony. The Chinese reciprocated with gifts such as silk, tea, and porcelain.

China sent missions to foreign lands to stimulate "tributary trade". Probably expansion to Guangzhou and Hanoi during the Han Dynasty was stimulated by the desire to facilitate access to luxuries from the South Seas (Nanhai/Nanyang) (Wang 1958, p. 8). China's involvement with foreign nations at this time was largely passive, dependent on attracting foreigners to come to China, except for the dispatch of missions when not enough envoys were coming to China.

Confucian officials held merchants in low esteem. Classical Chinese civilization, formed in the northern hinterland, emphasized militarism, austerity, isolationism, rigid social hierarchy, and centralized rule. Ministers praised rulers who "despised gold and jade". Culture in the south emphasized different qualities: free enterprise, commercialism, social mobility, and a cosmopolitan attitude toward foreign contact. China's history has been marked by competition between these two visions.

Ironically, demand from the scholarly class ensured demand for luxuries. A Chinese scholar's studio was not complete without imports from the south such as ivory, tortoise shell, sandalwood, and sapanwood (Chang 1983, p. 10). Confucian traditions included "carrying jade and scents", "burning incense while reading", and "burning resins to provide light". The Han court was divided on the morality of trade. In 178 BCE some Chinese nobles were criticized for collaborating with merchants by investing in trade in salt, metals, and luxury goods. Thus not all the Chinese elite could resist the lure of commerce. Emperor Han Wudi espoused trade, but after he died in $87 \mathrm{BCE}$ trade was restricted. In $77 \mathrm{BCE}$ a head of a commandery in south China convicted of trading with foreigners was executed. 


\section{MARITIME SILK ROAD: HAN THROUGH SUI PERIODS}

Chinese artefacts from the Western Han Dynasty have been discovered in southern Thailand along with items from around the South China Sea, the Indian Ocean, and the Mediterranean, making this the oldest international port yet found in Southeast Asia (Bellina 2017). A Chinese mission between 2 and $5 \mathrm{CE}$ sailed to peninsular Thailand, and then went overland across the peninsula, from whence they sailed to India (Wang 1958, p. 20). A Chinese report describes:

chief interpreters attached to the Yellow Gate (eunuchs serving in the palace) who go to sea with the men who answer their appeal (for a crew) to buy bright pearls, pi-liu-li (opaque glass), rare stones and strange things, taking with them gold and various fine silks to offer in exchange ... The merchant ships of the barbarians are used to transfer them (the Chinese) to their destination. (Wheatley 1961, pp. 8-13)

In 245-250 CE, soon after China was divided during the Three Kingdoms period, the southern kingdom of $\mathrm{Wu}$ sent two envoys on a mission to Funan (扶南, in today's Cambodia). They travelled in foreign ships. They were impressed by Funan, where they met ambassadors from India (Çœdès 1968, p. 42). Perhaps as a result of Chinese missions abroad, more foreign missions began to visit China. Between CE 284 to 287, 22 countries came to present tribute.

\section{EARLY COMMERCE IN CHINA}

Chinese economic history is poorly documented. The "first emperor", Qin Shihuang, sent half a million soldiers to conquer the Yüeh people south of the Yangzi. Fujian and Guangdong were defeated only after China sent reinforcements, including "criminals, banished men, social parasites and merchants" (Wang 1958). We know very little about the early merchants forced to join the military expedition to the south. Despite Confucian prejudice, some Chinese flaunted their Southeast Asian luxuries (Wang 1958, p. 35).

In $414 \mathrm{CE}$, late in the Three Kingdoms period, a Chinese Buddhist monk, Faxian, returned to China from India on a foreign ship carrying over 200 people, probably merchants. During the Southern Dynasties, 99 foreign tribute missions visited China, the vast majority (78) from Southeast Asia (Wang 1958, p. 51). Southeast Asian ports already specialized in particular products. One merchant, Zhang Qing Zhen, became rich by selling silk and brocade to people from the South Seas between 479 and 502 (Wang 1958, p. 60). A record from the Liu Song Dynasty describes how "ships came in a continuous stream, and merchants and envoys jostled with each other" (Wolters 1967, p. 77).

The History of the Qi (479-502) recorded that:

Of all the precious things in the world none are better than those of the southern barbarians ... Merchant ships arrive from afar and bring these things to the southern provinces. Thus, it is that Tongking and Kuangtung are rich and well stocked. The goods are stored in the imperial treasury. (Wang 1958, pp. 48 and 56 n32)

Chinese did not build large sea-going ships until the Song Dynasty. Chinese technology began to influence Southeast Asian ships in the fifteenth century (Manguin 1993). 


\section{IMPACT OF THE TANG DYNASTY}

During the Tang Dynasty, 24 countries sent 71 missions to China, most from Southeast Asia (Wang 1958). Of these, the most avid was Champa, in south Vietnam; with 26; Srivijaya only sent 6 . This may indicate that much trade between these two kingdoms took place outside the official system, but Tang records do not mention any private Chinese traders voyaging overseas. Probably illicit trade took place in China. A report about the governor of Lingnan in $820 \mathrm{CE}$ provides insight into the problem of corruption in port administration: "When the foreign ships arrive ... There is an examination of the merchandise. Rhinoceros (horns) and pearls were so numerous that bribes were offered to the servants and retainers; the Governor stopped this" (Wang 1958, p. 101).

Valuable information about the Asian maritime network in the late seventh century is found in the description of travels by a Chinese Buddhist monk-adventurer named Yijing (Sen 2018). Early Chinese pilgrims to India travelled overland, but by the late seventh century the sea route had become more popular. Yijing records that of 60 Chinese pilgrims who went to India, 22 went overland, while almost twice as many (37) travelled on merchant ships.

Srivijayans were leaders of the foreign merchant community at Guangzhou until 742 CE. Yangzhou became the main centre of trade in China after a road connecting this port to Guangzhou was built in 728. As a result, "The various countries from across the sea may now daily transport their merchandise, so that the wealth ... can ... meet the needs of the treasury and ... satisfy the demands of the Qiang-Huai region" (Wang 1958, p. 79). Through the eighth and into the early ninth century, trade continued to expand. Guangzhou in particular benefited from this expansion. A source from $841 \mathrm{CE}$ says, "Guangzhou enjoyed the profits of the barbarian ships where all the valuable goods were gathered ... Of all those who served at Guangzhou, not one returned without being fully laden (with the wealth they acquired)" (Wang 1958, p. 83).

In the early ninth century, when foreign ships arrived the emperor was notified, and announcements were made in major cities. Cargoes were taken to official warehouses where officials took custody of specific luxury items for the imperial family. When the last ship of the season arrived, the officials took another 30 per cent of the goods as duty. The foreign missions were then allowed to sell them to designated Chinese (Wang 1958; Hirth \& Rockhill 1911, p. 15). This system still existed when the Portuguese reached Guangzhou in the early sixteenth century (Cortesao 1944). They do not mention private commerce, bargaining, or money; after the government confiscated its share of the cargo, some was kept for the emperor and some was sold by the government. The rest was exchanged with local merchants at fixed rates. By 820 , Chinese merchants had begun to sojourn in Southeast Asia despite regulations forbadding Chinese to engage in private trade with foreigners. By the ninth century, members of the imperial family, regional aristocrats, and civil servants were all benefiting from the wealth which the Silk Road of the Sea generated (Wang 1958).

One of the greatest archaeological discoveries in Southeast Asia is a shipwreck found near Belitung Island, Indonesia. The ship, which probably sank between 830 and 840 (Wilson \& Flecker 2010), was built in the Persian Gulf (Flecker 2000). The ship may have been one of the first to carry a huge cargo of mass-produced Chinese pottery. It also carried gold artefacts of imperial quality, silver ingots, and star anise. Its crew probably included Southeast Asians; several items might have belonged to Chinese passengers (Krahl et al. 2010, p. 40). Pottery from Changsha was possibly meant for general distribution, but some artefacts are of such 
high quality that they must have been gifts for foreign royalty. The huge quantity of pottery on the ship (possibly 100,000 pieces) is the first evidence in the world of production for export on such an industrial scale. The pottery was made in many parts of China, indicating that the voyage had been carefully planned in advance and the loading had been well coordinated.

Where was the ship bound? Some believe that it was returning to the Indian Ocean (Guy 2001-2002, p. 25; Hsieh 2010, p. 142). The place where the ship sank is not on the normal route to the Indian Ocean; it is on the normal route from the South China Sea to Java still used today. The cargo probably included imperial gifts sent in response to a Javanese diplomatic mission. Java sent six embassies to China between 813 and 839 (Louis 2010, p. 91).

China's experience with Arab and Persian traders was complicated. In $758 \mathrm{CE}$ the Persian and Arab communities in Guangzhou, distressed by official corruption, sacked the port and fled (Wang 1958, p. 79). Five years later Persian and Arab merchants living in the port of Yangzhou were massacred by anti-Tang rebels. China lost control of the overland Silk Road in the same year. In 760-761 Arabs requested permission to trade in Java. This brought great prosperity to Java and Srivijaya in Sumatra (Wheatley 1961, p. 218). Guangzhou recovered, but in 878 was sacked again, this time by a rebel Chinese general. The foreign merchants returned to the Malay Peninsula and Sumatra. Despite this turmoil, Chinese ceramics became a major export item in the ninth century. Tang ceramics are found on many sites along the Asian maritime network, from Indonesia to the Persian Gulf.

\section{THE FIVE DYNASTIES (907-959)}

Soon after the fall of the Tang, a Southeast Asian ship called the Intan sank in the sea lane off south Sumatra with a large cargo of Chinese porcelain (Flecker 2002). The ship was made in Southeast Asia but had bulkheads suggesting Chinese influence. A heavy load of tin ingots probably came from the Malay Peninsula, above which were Chinese ceramics. This suggests that imported Chinese merchandise were stored in Southeast Asian ports, from which they were re-exported to other areas, in other words that trans-shipping of cargoes was already practised. At least 137 Chinese coins were on board, suggesting that they might already have been used in Southeast Asia. The ship carried at least 100 silver ingots with inscriptions.

The Intan gives clear evidence that trade between China, Indonesia, and the Indian Ocean was tightly integrated during the Tang era. The ship carried items from all three regions. Shipwrecks from the Song Dynasty have similar cargoes, suggesting that the Asian maritime trade network formed at this time remained stable for a long period.

\section{THE SONG DYNASTY}

The foundation of the Song Dynasty in 960 ushered in a new period of trade when many more parties became involved in trade. The Song sent four missions abroad in 984-988, with imperial edicts, gold, and cloth to exchange for Southeast Asian luxuries (Sen 1996). By $1000 \mathrm{CE}$ the Song had opened six ports to foreign trade.

Pingzhou Ketan describes a ship being loaded with cargo bound for the South Seas (Yang 1985, p. 26). This description is illustrated by another ship found in the Java Sea, the Cirebon, which probably sank in the late tenth century. The ship was a typical Indonesian vessel with 
a cargo weighing at least 300 tons (Liebner 2010, p. 33), including perhaps 500,000 Chinese ceramics. This indicates that foreign demand fuelled rapid growth of the Chinese ceramic industry.

In 1025 the Chola kingdom in south India conquered all major ports in the Straits of Melaka (Kulke, Kesavapany \& Sakhuja 2009). It has been suggested that this attack was occasioned by Chola ambition to abolish Srivijaya's monopoly of trade with China, but there is no evidence to support this. The Chola did not expand their trade with China; they were content to set up trading centres in north Sumatra and south Thailand where Indian trading guilds may have resided seasonally. Few Chinese ceramics have been found in south India. No descriptions of early Chinese quarters in India exist.

\section{CHINA'S ROLE TRANSFORMED FROM PASSIVE TO ACTIVE}

During the Tang and Northern Song dynasties (up to 1126) it was a capital offence to go abroad without official permission. In 1126 the Song lost control of the northern part of the empire. During the Southern Song Dynasty, official trade was greatly expanded, partly in order to secure additional revenue. More importantly, Chinese merchants were allowed for the first time to go to Southeast Asia (Sen 1996, p. 258). In 1137 Emperor Gaozong issued an edict that "The profits from maritime commerce are very great. If properly managed, they can bring a million (strings of cash). Is this not better than taxing the people?" (Ma 1971, p. 34). Gaozong's projections were actually conservative; in 1128 tax on maritime trade had already yielded two million strings, 20 per cent of the government's revenue (Tan 2005, p. 232). Complexity of maritime trade in the Southern Song is illustrated by a Chinese inventory of 1141 which listed 339 types of imports (Wheatley 1959, p. 31).

As usual, official records on this transition are almost non-existent, but some signs of a new era can be detected. The first quantitative records of tribute received from Southeast Asia appear during the Southern Song period. In 1135, a Sumatran kingdom sent 55 tons of frankincense to China (Wheatley 1959, p. 40). This shows that the amounts of produce brought to China as tribute in the Southern Song were still substantial. China's annual imports increased ten-fold between 1053 and 1175 (Wheatley 1961, p. 61). Chinese merchants who convinced foreigners to bring cargoes yielding 50,000 strings worth of duties received an official title (Wheatley 1959, p. 25). The nobility became rich through participating in maritime trade. Clan members could expropriate ships from merchants, which made them unpopular among the merchants. Maritime trade became deeply intertwined in Chinese politics. A Chinese man who had lived in Indonesia for a long time, his Indonesian wife, and some other "dark natives" were rescued from a shipwreck on the coast of China in 1150 (Hirth 1917, p. 76). The oldest Chinese-built ship yet found outside of China was discovered off the north tip of Sabah. It dates to the Southern Song (Flecker 2012, p. 27).

Locally made coins of gold and silver existed in much of Southeast Asia during the first millennium $\mathrm{CE}$, but they were inefficient because they were useless for small purchases. Starting in the Song era, Chinese coins became a medium of exchange in western Indonesia. This efficient currency was one of China's most important contributions to premodern Southeast Asia's economy. The Chinese government was, however, unhappy about the export of Chinese currency. In 1074 an official complained that foreign ships were so full of Chinese 
coins that "the currency was drained off like the waters of the sea into the wei-lu [rear gate]" (Rockhill 1914, p. 422).

In 1189 the export of silver was banned, like bronze coins (Von Glahn 2004, p. 175). This ban like many others was ineffective, as Chinese silver ingots, some with official stamps on them, found on Southeast Asian shipwrecks of this period attest. Pottery export was officially encouraged (Wheatley 1959, p. 39). Porcelain production surged, offsetting to some extent the imbalance of trade (Yang 1985, p. 27). Zhu Yu, in the early 1100s, described Chinese merchants going abroad, taking mainly pottery, "the small pieces packed in the larger, till there is not a crevice left" (Hirth and Rockhill 1911, p. 31). The problem was only ameliorated when the Yuan introduced paper money.

In 1225 an important work which describes trading ports in Indonesia and the Indian Ocean in great detail (Hirth \& Rockhill 1911), Zhu Fan Zhi ("Records of Various Foreign Lands"), was written by the harbourmaster of Guangzhou, Zhao Ruguo. It was no longer necessary to have diplomatic recognition from China to trade with China (Wolters 1970). As a result of the increased trade and the new freedom of Chinese merchants to go abroad, many new ports appeared in Southeast Asia, all competing for the China market. The Zhu Fan Zhi states that porcelain trade at this time was mainly conducted by foreign merchants (fan shang). The best-known Song Dynasty period archaeological site in Southeast Asia where Chinese may have sojourned (i.e. stayed for a few years) cannot be identified with any of the ports mentioned by Zhao. The site, known by the modern name Kota Cina, lies on the coast of northeast Sumatra.

The name is Indonesian for "Chinese stockade". Marco Polo described how a Chinese fleet built a stockade in north Sumatra in 1292 where they lived for five months while awaiting the return of favourable winds (Latham 1958, p. 254). The fact that they did not spend the monsoon in an existing Chinese community suggests that one did not exist at this time. Probably Kota Cina had already been abandoned. The large fleets of the early Ming Dynasty also built temporary encampments (Mills 1970, p. 113).

Archaeological excavations at Kota Cina (Miksic 1979) discovered brick temple foundations, posts of stilt houses, and large quantities of Chinese ceramics and coins dating from 1080 to 1260 . Chinese presence at Kota Cina is suggested by several factors. Many bronze Chinese coins were found, some still in boxes and corroded together in sausages, indicating that they were originally tied in strings. This is the oldest known site in Southeast Asia where Chinese cash was in circulation. Some pieces of gold foil are inscribed with Chinese characters.

\section{THE YUAN DYNASTY}

The Yuan Dynasty (founded in 1260) fought with Vietnam, Champa, Cambodia, and Burma, in order to maintain "tributary trade". In 1329, however, the court decided that tributary trade was "a canker devouring the riches of the state" involving useless luxuries which had to be exchanged for Chinese goods at fixed rates (Wheatley 1961, p. 77). Private trade seems to have flourished in the last 40 years of the dynasty.

A shipwreck called the Java Sea provides important data about maritime trade in the early Yuan. The inventory is not greatly different than that of the Intan 300 years earlier. The main items on the wreck off southeast Sumatra were ceramics and iron. The iron cargo, made up of 
iron bars and cauldrons, was approximately 340 tons; the ceramic cargo, consisting of 100,000 items, weighed 25-30 tons (Mathers and Flecker 1997).

\section{OVERSEAS CHINESE COMMUNITIES}

There are no descriptions of overseas Chinese communities before the fourteenth century. By the early fifteenth century there were communities of several thousand Chinese in Java, Sumatra, and Thailand. In 1349 a gazetteer, Qingyuan xuzhi ("A Continuation of the History and Topography of Quanzhou"), was compiled, including a section entitled Daoyi zhilue ("Description of the Barbarians of the Isles") written by a Chinese merchant named Wang Dayuan (Rockhill 1914) who made two voyages to Nanhai between 1330 and 1339. Wang is the first known Chinese merchant to have written about his experiences abroad. He provided a detailed guide to commerce in 99 places, of which 60 are in Southeast Asia, 36 in the Indian Ocean, and three in East Asia.

Wang mentions only two overseas Chinese communities, but he may have omitted others. One of these two communities consisted of soldiers who sailed on a Yuan fleet sent to attack Java in 1292. Those who fell ill during the voyage were left on an island off west Borneo. In Wang's day, 40 years later, "over 100" of these men were still alive, "mixed up with the native families" (Rockhill 1914, p. 261). The other overseas Chinese lived in a port which is today Singapore (Wheatley 1961).

During the late Yuan Dynasty Singapore became a prosperous settlement with exceptional access to high quality Chinese ceramics and glassware. Singapore paid tribute to the kingdoms of Majapahit in Java, Ayutthaya in Thailand, and China, where it sent a mission in 1325. In the early fifteenth century Melaka replaced Singapore as the main port in the southern Strait of Melaka, but Singapore remained the centre of the sultanate's naval power. Shun Feng Xiang Song ("Fair Winds for Escort"), written around 1430, mentions Singapore as a place where passengers could change ship (Mills 1970, p. 325), suggesting that it was a connecting point between regional and long-distance shipping routes.

Excavations in Singapore have yielded much Chinese pottery, glass, and coins of the Yuan and Ming Dynasties. The archaeological discoveries in Singapore provide a detailed image of a precolonial port on the Asian maritime trade network with an ethnically heterogeneous population. A palace and temple complex, workshop zones, and residences have been identified. Chinese and Sri Lankan currencies were in general use.

\section{THE MING DYNASTY}

The Ming Dynasty (1368-1644) reverted to an anti-commercial policy; Chinese ports lost the prosperity and importance they had attained during the Song-Yuan era. The first Ming emperor reinstated harsh penalties for unauthorized contact with foreigners. In 1371 he severely punished Fujian officials who sent merchants abroad. New laws banished minor offenders to hard labour at the frontier; major offenders were executed. In 1402 a law was passed threatening to send a fleet abroad to kill all overseas Chinese who refused to return to China (Nie 1997). Three centuries of increasing Chinese involvement in the Asian maritime network came to a halt. 
In 1402 the third Ming emperor, Yongle, took the throne. The nobility continued their tradition of demanding foreign luxuries. One of the most famous acts of Yongle's reign was the dispatch of large fleets as far as Africa to collect tribute. China did not control the overland silk route; the famous Tamerlane ruled central Asia. After the last tribute-gathering expedition in 1430, China severed contact with the outside world for 75 years.

Palembang, the ancient capital of the kingdom of Srivijaya, is the first known place to be governed by overseas Chinese. Palembang was attacked by Java in the Hongwu period and the Indigenous population fled, leaving a large Chinese community behind. The Chinese in Palembang considered themselves to be an independent Southeast Asian kingdom. Yongle decided to tolerate them and created a special office to deal with them (Kobata \& Matsuda 1969), somewhat analogous to the "one country, two systems" principle. Palembang sent tribute to China in 1405 and 1406, in a similar manner to other Southeast Asian kingdoms. The leader was deposed in 1407 by another Chinese who was not officially recognized by Yongle. In 1408 Admiral Zheng He went to Palembang, arrested the man, and installed a replacement. His son in 1424 requested Chinese investiture as his father's successor. The next ruler, a woman, succeeded her father. The fact that a woman could be chosen as the ruler of the Palembang community is more common in Southeast Asian than Chinese custom. Palembang Chinese seem to have absorbed a significant amount of Southeast Asian culture.

After China closed its doors, overseas Chinese leaders urged their people to assimilate to local society (Ma 2002). Tome Pires, a Portuguese who was in Melaka in 1515, described Palembang as culturally Javanese/Malay. Chinese communities in Java also seem to have adopted local identity during the fifteenth century.

\section{MARITIME ARCHAEOLOGY OF THE MING PERIOD}

Over 30 shipwrecks from the fifteenth century have been found in Southeast Asia, indicating that the Asian maritime network continued to be active in the absence of the Chinese. Many of these ships carried Southeast Asian ceramics which filled the vacuum left by the absence of Chinese pottery. The Bakau wreck found near Belitung Island, Indonesia, not far from the Tang Dynasty Belitung wreck (Flecker 2001), sank in the main shipping lane between the South China Sea and Java. The cargo included Thai, Vietnamese, and Chinese ceramics and coins of the Yongle reign (Flecker 2001, p. 226). Iron was also in the cargo. The ship is a typical flat-bottomed Chinese vessel. It was on a smuggling voyage when it sank, precisely during the era when the Yongle emperor was trying to restrict contact with foreigners to official channels. This discovery is a salutary reminder that archaeological research has much greater potential than historical sources to shed light on early Chinese maritime contact with Southeast Asia.

\section{CONCLUSION}

There are some close parallels between the current BRI and the golden age of Chinese maritime trade in the Tang (618-906), Song (960-1279) and Yuan (1260-1367) dynasties, and some differences. During the Tang period, Chinese did not venture abroad, preferring to allow foreigners to come to China, albeit their movements were limited to specific ports. During 
the Song and Yuan Dynasties, Chinese began to travel abroad and stay away from China for longer periods until eventually permanent overseas Chinese communities formed. In the BRI, China has taken the initiative to plan development of infrastructure for foreign ports; this is an unprecedented situation. In the Tang-Song-Yuan era, Chinese merchants had to design their exports to suit foreign consumer tastes. In the BRI era, foreign countries have begun to follow Chinese fashions and popular culture. The long-term development of overseas Chinese communities in Southeast Asia has led to closer cooperation in the design of projects. The situation in countries bordering the Indian Ocean is somewhat different, since no major overseas Chinese communities developed there.

In 1500, most Chinese communication with the outside world took place through smuggling. Anyone who built ships with more than two masts, or traded in foreign countries, would be executed. Those who chartered ships to seafarers, shared foreign goods, or traded over 1,000 kati of sapanwood and pepper, were banished to serve as frontier guards (Chang 1983, p. 49). The benefits of trade which accrued to China during the Song and Yuan era were lost due to the isolationist policies of the Ming and Qing. Due to the lack of documentary sources, details of this early period of overseas Chinese commerce were forgotten until recent archaeological research began to shed light on them.

The assumption that pre-revolutionary China was an inward-looking land-locked empire is not completely true. The Tang-Song-Yuan era was an earlier phase during which China became active in private trade, and all of maritime Asia benefited greatly from expanding maritime commerce. Greater knowledge of the history of this early sphere of prosperity and how it functioned could provide an example of how the future relationship between China and the rest of maritime Asia could be organized.

The initiative of the Chinese government to foster research on the premodern relations between China and the Indian Ocean region has yielded new data which are not previously known. Much more research, particularly in archaeology, would reveal many more details of the economic and cultural benefits of this early period of increased trade and communication. Closer cooperation between China and all countries connected with the BRI in the fields of historical and archaeological research could benefit both sides by demonstrating the potential benefits of more efficient maritime communication and trade which already appeared in ancient times.

\section{REFERENCES}

Bellina, B. (ed.) (2017), Khao Sam Kaeo: An Early Port-City between the Indian Ocean and the South China Sea. Paris: École française d'Extrême-Orient, Mémoires archéologiques.

Chang, P.T. (1983), Chinese Maritime Trade: The Case of 16th-Century Fu-chien (Fukien). PhD thesis, Princeton University, NJ.

Çœdès, G. (1968), The Indianized States of Southeast Asia. Walter F. Vella (ed.), Susan Brown-Cowing (trans.). Honolulu: University of Hawaii.

Cortesao, A. (ed. and trans.) (1944), The Suma Oriental of Tome Pires. 2 vols. London: Hakluyt Society.

Flecker, M. (2000), 'A 9th-century Arab or Indian shipwreck in Indonesian waters', The International Journal of Nautical Archaeology, 29 (2), 199-217.

Flecker, M. (2001), 'The Bakau wreck: An early example of Chinese shipping in Southeast Asia', The International Journal of Nautical Archaeology, 30 (2), 221-230.

Flecker, M. (2002), The Archaeological Excavation of the 10th Century Intan Shipwreck. BAR International Series 1047. Oxford: Archaeopress. 
Flecker, M. (2012), 'The Jade Dragon wreck: Sabah, East Malaysia', The Mariner's Mirror, 98 (1), 9-29.

Guy, J. (2001-2002), 'Early Asian ceramic trade and the Belitung ("Tang”) Cargo', Transactions of the Oriental Ceramic Society, 66, 13-27.

Hirth, F. (1917), 'Chau Ju-kua, a new source of mediaeval geography', China and the Chinese, 76.

Hirth, F. and Rockhill, W. (1911), Chau Ju-kua. St. Petersburg: Imperial Academy of Sciences.

Hsieh, M. (2010), 'The navigational route of the Belitung Wreck and the late Tang ceramic trade', in R. Krahl, J. Guy, J.K. Wilson, and J. Raby (eds), Shipwrecked: Tang Treasures and Monsoon Winds. Washington, DC: Arthur M. Sackler Gallery, Smithsonian Institution; Singapore: National Heritage Board, Singapore Tourism Board, pp. 137-143.

Hung, H.-C., Iizuka, Y., Bellwood, P., Nguyen, K.D., Bellina, B., Silapanth, P., Dizon, E., Santiago, R., Datan, I., and Manton, J.H. (2007), 'Ancient jades map: 3,000 years of prehistoric exchange in Southeast Asia', Proceedings of the National Academy of Sciences, 104 (50), 19745-19750.

Kobata, A. and Matsuda, M. (1969), Ryukyuan Relations with Korea and South Sea Countries. Kyoto: Atsushi Kobata.

Krahl, R., Guy, J., Wilson, J.K., and Raby, J. (2010), 'The crew and their possessions', in R. Krahl, A. Effeny, A. Science, A.M. Sackler, and E. Al (eds), Shipwrecked: Tang Treasures and Monsoon Winds. Washington, DC: Arthur M. Sackler Gallery, Smithsonian Institution, Cop, p. 40.

Kulke, H., Kesavapany, K., and Sakhuja, V. (2009), Nagapattinam to Suvarnadwipa: Reflections on the Chola Naval Expeditions to Southeast Asia. Singapore: Institute of Southeast Asian Studies.

Latham, R. (trans.) (1958), The Travels of Marco Polo. Harmondsworth: Penguin.

Lattimore, O. (1962), Inner Asian Frontiers of China. Boston, MA: Beacon.

Liebner, H. (2010), 'Cargoes for Java: Interpreting two tenth-century shipwrecks'. Paper presented to the 13th International Conference of the European Association of Southeast Asian Archaeology, Berlin.

Louis, F. (2010), 'Metal objects on the Belitung shipwreck', in R. Krahl, J. Guy, J.K. Wilson, and J. Raby (eds), Shipwrecked: Tang Treasures and Monsoon Winds. Washington, DC: Arthur M. Sackler Gallery, Smithsonian Institution; Singapore: National Heritage Board, Singapore Tourism Board, pp. 85-91.

Ma, L. (1971), Commerce Development and Urban Change in Sung China. PhD dissertation, University of Michigan, Ann Arbor, MI.

Ma, R. (2002), 'Chinese Muslims in Malaysia in different periods of history', in Colloquium on Chinese Scholarship on the Malay World Studies, 16-17 September 2002. Bangi: Universiti Kebangsaan Malaysia, pp. 103-119.

Manguin, P-Y (1993), 'Trading ships of the South China Sea: Shipbuilding techniques and their role in the history of the development of Asian trade networks', Journal of the Economic and Social History of the Orient, 36, 253-280.

Mathers, W.M. and Flecker, M. (eds) (1997), The Archaeological Recovery of the Java Sea Wreck. Annapolis: Pacific Sea Resources.

Miksic, J.N. (1979), Archaeology, Trade, and Society in Northeast Sumatra. Doctoral Dissertation, Cornell University, Ithaca, NY.

Miksic, J.N. (1984), 'A comparison between some long-distance trading institutions of the Malacca Straits area and of the western Pacific', in D.T. Bayard (ed.), Southeast Asian Archaeology at the XV Pacific Science Congress. Studies in Prehistoric Anthropology Volume 16. Dunedin: University of Otago, pp. 235-253.

Mills, J.V.G. (ed. and trans.) (1970), Ma Huan, Ying-yai Sheng-lan. Cambridge: Hakluyt Society.

Nie, D. (1997), 'Chinese merchants and their maritime activities under the ban on maritime trade in the Ming Dynasty (1368-1567)', Ming Qing Yanjiu, 6, 69-92.

Rockhill, W.W. (1914), 'Notes on the relations and trade of China with the eastern archipelago and the coast of the Indian Ocean during the fourteenth century', T'oung Pao 15, Part 1, 419-447; Part 2, 61-159, 236-271, 374-392, 435-467, 604-626.

Sen, T. (1996), 'Administration of maritime trade during the Tang and Song Dynasties', China Report, 32 (3), 251-265.

Sen, T. (2018), 'Yijing and the Buddhist cosmopolis of the seventh century', in H. Saussy (ed.), Texts and Transformations: Essays in Honor of the 75th Birthday of Victor H. Mair. Amherst: Cambria Press, pp. 345-368. 
Tan, R.C. (2005), 'Prosperity in Quanzhou during the 12th-14th centuries and its impact on the ceramic industry of Fujian with reference to Philippine finds', in C. Pei-Ki, L. Guo, and W.C. $\mathrm{Ki}$ (eds), Proceedings of the International Conference: Chinese Export Ceramics and Maritime Trade, 12th-15th Centuries. Hong Kong: Chinese Civilisation Centre, University of Hong Kong, pp. 230-252.

Von Glahn, R. (2004), 'Revisiting the Song monetary revolution: A review essay', International Journal of Asian Studies, 1 (1), 159-178.

Wang, G. (1958), 'The Nanhai Trade: A study of the early history of Chinese trade in the South China Sea', Journal of the Malaysian Branch of the Royal Asiatic Society, 31 (2), 1-135.

Wheatley, P. (1959), 'Geographical notes on some commodities involved in Sung maritime trade', Journal of the Malaysian Branch of the Royal Asiatic Society, 32 (2), 1-140.

Wheatley, P. (1961), The Golden Khersonese. Kuala Lumpur: University of Malaya Press.

Wilson, J.K. and Flecker, M. (2010), 'Dating the Belitung Shipwreck', in R. Krahl, J. Guy, J.K. Wilson, and J. Raby (eds), Shipwrecked: Tang Treasures and Monsoon Winds. Washington, DC: Arthur M. Sackler Gallery, Smithsonian Institution; Singapore: National Heritage Board, Singapore Tourism Board, pp. 35-37.

Wolters, O.W. (1967), Early Indonesian Commerce. Ithaca, NY and London: Cornell University.

Wolters, O.W. (1970), The Fall of Srivijaya in Malay History. Ithaca, NY and London: Cornell University.

Yang, B. (2010), 'The Zhang on Chinese southern frontiers: Disease constructions, environmental changes, and imperial colonization', Bulletin of the History of Medicine, 84 (2), 163-192.

Yang, S. (1985), 'A brief account of ceramic exports from Guangdong during the Tang and Song Dynasties', in Ceramic Finds from Tang and Song Kilns in Guangdong. Hong Kong: Fu Ping Shan Museum, University of Hong Kong, pp. 22-31. 